\title{
Les céramistes d'art, « satellites » du champ artistique
}

Hétéronomie négociée, autonomisation du groupe et renouvellement du champ

Artistic Ceramists, «Satellites » of the Artistic Field. Negotiated Heteronomy, Group Autonomization, and Renewal of the Field

Los ceramistas artísticos, "satélites » del campo artístico. Heteronomía negociada, autonomización del grupo y renovación del campo

\section{Flora Bajard}

\section{OpenEdition}

\section{Journals}

Édition électronique

URL : http://journals.openedition.org/bssg/324

DOI : $10.4000 /$ bssg.324

ISSN : 2490-9424

Éditeur

Presses universitaires de Vincennes

Référence électronique

Flora Bajard, "Les céramistes d'art, " satellites » du champ artistique », Biens Symboliques / Symbolic Goods [En ligne], 4 | 2019, mis en ligne le 27 juin 2019, consulté le 04 mars 2021. URL : http:// journals.openedition.org/bssg/324; DOI : https://doi.org/10.4000/bssg.324 


\section{Les céramistes d'art, " satellites » du champ artistique}

Hétéronomie négociée, autonomisation du groupe et renouvellement du champ

\section{Artistic Ceramists, "Satellites" of the Artistic Field}

\author{
Negotiated Heteronomy, Group \\ Autonomization, and Renewal of the Field
}

\author{
Flora Bajard \\ traduction | translation \\ Daniela Ginsburg
}

Aujourd'hui, les céramistes d'art sont environ 2000 en France ${ }^{1}$. Ils exercent sous des statuts variés (artiste, artisan, autoentrepreneur, entrepreneur salarié en coopérative, profession libérale...), et dans des espaces commerciaux éclectiques (du marché de potier à la galerie d'art, en passant par des boutiques de décoration). Ils utilisent un matériau commun, l'argile, pour fabriquer des pièces utilitaires (pichets, assiettes, tasses, plats...) ou uniques et sculpturales. Les céramistes forment une communauté socio-professionnelle autonome vis-à-vis des autres professions artisanales et artistiques, dotée d'un nomos propre et de nombreuses instances et logiques de régulation. Cela n'empêche bien sûr pas les fractionnements internes et les dissensions ${ }^{2}$, mais ce groupe professionnel reste

1. II n'existe pas de recensement administratif des céramistes d'art, puisqu'ils·elles exercent sous des statuts légaux variés. La liste la plus exhaustive reste à ce jour l'« annuaire » édité tous les quatre ans par les éditions de La Revue de la céramique et du verre, que nous avons combiné à notre pratique du terrain afin d'évaluer la proportion de non-inscrits dans ce guide.

2. Pour une analyse du « mythe de la base » chez les céramistes et de la manière dont certains leaders associatifs ont transformé leur vision du métier en « bonnes pratiques », nous renvoyons au chapitre 6 de l'ouvrage de Flora Bajard (Bajard 2018a).
There are around 2,000 artistic ceramists in France today. ${ }^{1}$ They practise under various professional categories (artist, craftsperson, self-employed, salaried self-employed person in a cooperative, liberal professional, etc.) and in a range of commercial spaces (from pottery markets to art galleries by way of home decor shops). They use a common material, clay, to create either utilitarian pieces (pitchers, plates, mugs, platters, etc.) or unique, sculptural works. Ceramists form an autonomous socio-professional group with respect to other artistic and artisanal professions, and have their own nomos as well as numerous regulatory bodies and systems. Of course, there are still internal fractures and points of disagreement, ${ }^{2}$ but the professional group remains strongly

1. There is no administrative census of artistic ceramists, since they ractise under various legal statuses. The most exhaustive list remains the "directory" published every four years by the journal La Revue de la céramique et du verre, to which I referred in combination with my fieldwork in order to assess the proportion of those not included in that directory.

2. For analysis of ceramists' "base myth" and of how certain association leaders transformed their view of the profession into "best practices," see Flora Bajard's book (2018a: chapter 6). 
fortement structuré autour de normes informelles (rhétorique professionnelle) ou formelles (prises de position des associations de professionnels, par exemple). Cette question de l'autonomie des activités renvoie à des logiques très variables en sociologie ${ }^{3}$. Les travaux de Pierre Bourdieu sont, à ce titre, fondateurs, et la notion permet alors de penser le degré d'indépendance d'un espace social vis-à-vis de déterminations externes, en particulier en matière économique, religieuse et politique. $\mathrm{Ce}$ faisant, l'autonomie interroge le degré " d'arbitraire social de la croyance » propre à un champ, soit la force de sa cohérence et de ses logiques propres ${ }^{4}$. Bernard Lahire, reprenant les travaux bourdieusiens, remarque ainsi qu'une première acception renvoie au principe de différenciation, de spécialisation et de division du travail qui conduit à distinguer une activité des autres. Le degré d'autonomie d'un univers social s'évalue de ce point de vue «à sa capacité à agencer des activités spécifiques, selon ses règles propres, avec des institutions et des catégories de jugement spécifiques " (Lahire 2006 : 49). En sociologie des professions, cela renvoie à l'idée d'une maîtrise des activités à réaliser, ressources mobilisables, buts et significations associées au travail par le groupe professionnel lui-même (Demazière 2009 : 88). Une seconde acception de l'autonomie renvoie à l'idée d'indépendance vis-à-vis des autres espaces, et le degré d'autonomie se mesure alors à la capacité d'un univers social à " organiser les moyens de subsistance de ses membres, c'est-à-dire [...] sa capacité à produire et reproduire un corps de professionnels largement dédiés

3. L'autonomie dont il est question dans cet article est, par exemple, un peu différente de l'autonomie individuelle dont disposent (ou pas) les travailleur·euse·s dans leur activité, même si ces deux acceptions sont liées (cf. : infra).

4. De très nombreux travaux bourdieusiens sont fondés sur cette idée. Parmi bien d'autres, voir par exemple l'article de Pierre Bourdieu (1976). structured around informal and formal norms (professional rhetoric and, for example, the positions taken by professional associations). Within sociology, the question of the autonomy of professional activities corresponds to a wide variety of logics. ${ }^{3}$ The work of Pierre Bourdieu is foundational in this respect: the notion of autonomy makes it possible to understand the degree to which a social space is independent from outside determinations, in particular economic, religious, and political. In this way, the concept of autonomy can be used to assess the degree of "social arbitrariness of belief" specific to a field-that is, the strength of its coherence and particular logics. ${ }^{4}$ Working in the Bourdieusian tradition, Bernard Lahire notes that there are two senses of the term of autonomy. The first corresponds to the principle of differentiation: the specialization and division of labour that leads to distinguishing one kind of work from another. From this point of view, the degree of autonomy of a social universe is evaluated according to "its capacity to organize specific activities, according to its own rules, with specific institutions and categories of judgment" (Lahire 2006: 49). In the sociology of professions, this is understood in terms of mastery of the activities to be performed, immediately available resources, and the goals and meanings associated with the work by the professional group itself (Demazière 2009: 88). A second sense of the term autonomy refers to independence from other spaces, and here the degree of autonomy is measured by the ability of a social universe to "organize its members' means of subsistence, that is... its capacity to produce and reproduce a body of professionals largely dedicated to their professional activity" (Lahire 2006: 49). This dynamic

3. The autonomy I discuss in this article is, for example, a bit different from the autonomy that labourers may or may not have in their work, even if the two senses are connected (see below).

4. Numerous Bourdieusian works are based on this idea. Among many others, see Pierre Bourdieu's article (Bourdieu 1976). 
à leur activité professionnelle » (Lahire 2006 : 49). Cette fois-ci, c'est en termes d'autonomie institutionnelle que cette dynamique peut être formulée en sociologie des professions : les membres d'un métier cherchent à s'organiser pour stabiliser, contrôler et faire reconnaître les frontières de leur activité et assurer sa pérennité ${ }^{5}$. Dans tous les cas, l'autonomisation ne saurait se réaliser sans aspérités, ambiguïtés ou résistances : plusieurs formes d'hétéronomie, comprise comme les règles et demandes formulées par des instances extérieures au groupe, pèsent sur un tel processus. Même lorsque ces règles externes s'avèrent être en conformité avec celles du groupe, cet ajustement n'est jamais acquis d'avance, ni définitif. C'est cet aspect dynamique, par lequel les normes d'un espace social sont toujours en jeu - et enjeu - qui nous semble central dans la notion d'hétéronomie.

5. La professionnalisation ne saurait se réduire, de manière téléologique, à l'acquisition permanente et linéaire de différentes formes d'autonomie, mais cela en constitue un dessein possible. Consistant en la diffusion de normes de professionnalité, la professionnalisation est en quelque sorte un ensemble de transactions et d'échanges entre in-group et out-group, c'est-à-dire une suite d'actions et de réactions à l'hétéronomie. can be expressed within the sociology of professions in terms of institutional autonomy: those who practise a certain profession or trade seek to organize themselves in order to stabilize, control, and gain recognition for the boundaries of their profession and to ensure that it will survive. ${ }^{5}$ In both senses, autonomization always involves difficulties, ambiguities, and resistance: various forms of heteronomy-understood as the rules and demands imposed by bodies outside of the group-weigh on the process. Even when outside rules agree with those of the group, the process of adjustment is never guaranteed or definitive. To my mind, this dynamism, which means that the norms of a social space are always at stake - and in play - is central to the notion of heteronomy.

5. Professionalization cannot be reduced, in a teleological manner, to permanent and linear acquisition of various forms of autonomy, but that is one possible form of it. Professionalization consists in the diffusion of norms of professionalism; in a way, it is a set of transactions and exchanges between an in-group and an out-group - that is, a series of actions and reactions to heteronomy. 


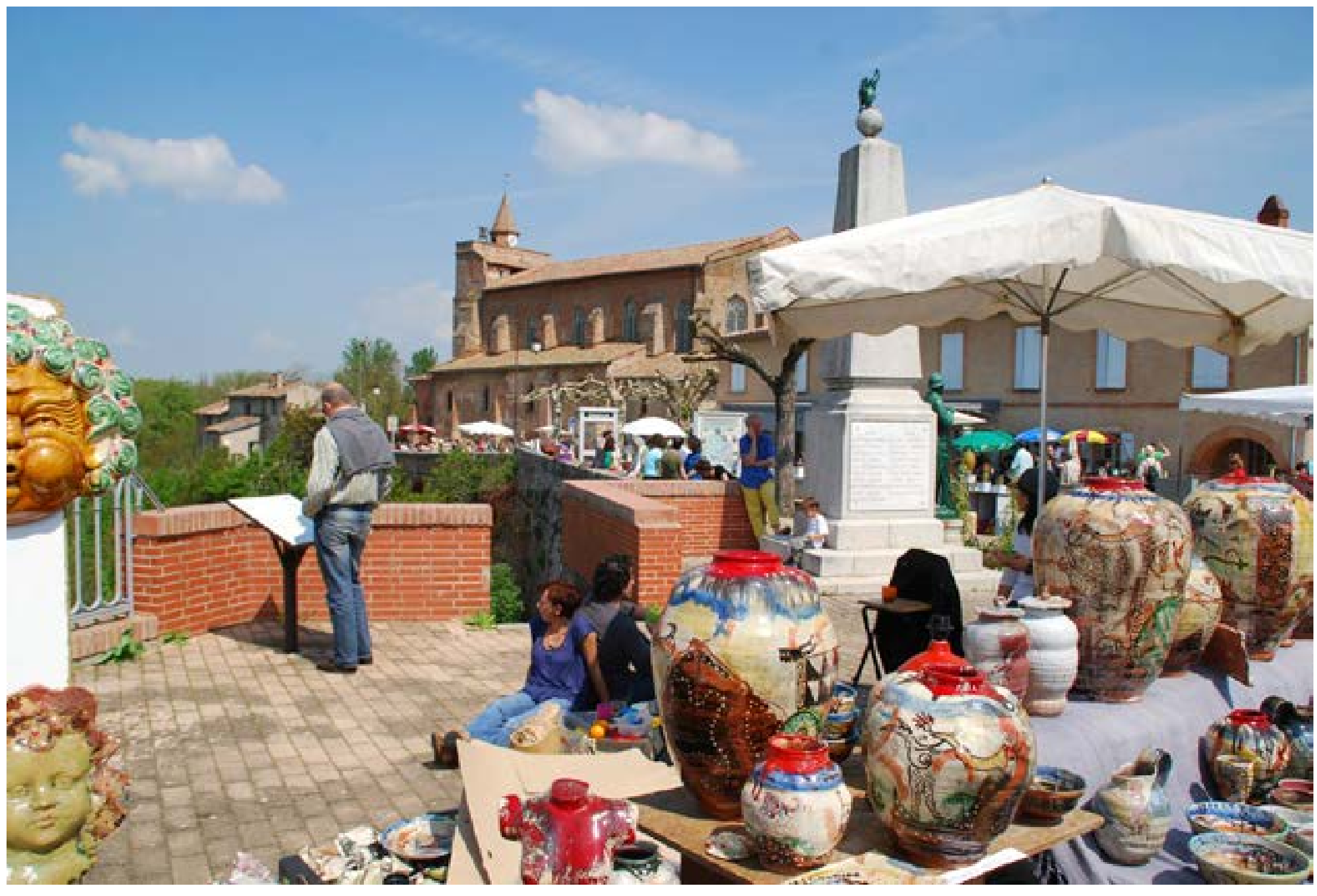

Fig. 1. Stand d'un marché de potiers reconnu au sein de la profession. Des jarres en terre vernissée et aux décors uniques, se rapprochant ainsi d'œurres non ou peu utilitaires, y sont exposées à côté de céramique utilitaire (bols, assiettes...).
Source : Flora Bajard.

Fig. 1. Market stand of ceramists recognized within the profession. Urns made of glazed earth, with unique decorations - in this respect similar to non-utilitarian or low-utility works - are displayed alongside utilitarian pieces 
Concrètement, cette dernière est donnée à voir parce que toute recherche d'autonomie se réalise généralement à travers une logique concomitante qui consiste, non sans ambivalences, en la recherche de soutien matériel et de reconnaissance symbolique auprès de sources d'autorité et de légitimité extérieures. Dans la sociologie des professions de manière générale, et chez Andrew Abbott par exemple, la protection d'un territoire professionnel est rendue possible par la lutte se déroulant à la fois sur le lieu de travail, dans les relations établies avec un public, et dans les interactions avec l'État. Cette perspective met ainsi en avant la place de divers « auditoires » qui, eux-mêmes, ne sont pas unifiés (collègues, public, État) dans la dynamique de constitution d'un territoire professionnel (Abbott 2003). Parce que certains segments du champ du pouvoir - administrations ministérielles, instances judiciaires - sont au cœur de la recherche d'autonomie du groupe professionnel étudié ici, c'est sur ceux-ci que nous nous focaliserons ${ }^{6}$. Ensuite, l'hétéronomie se manifeste lorsque des principes menacent directement les normes du groupe. D'ailleurs, si la sociologie bourdieusienne se réfère aux instances de pouvoir - en particulier économique - qui pèsent sur un champ pour désigner l'hétéronomie, il faut souligner que dans cet article la notion est pensée en fonction de l'objet auquel elle se rapporte : tantôt le groupe professionnel, tantôt le champ artistique. Cette distinction est importante, puisque les logiques des céramistes ne recoupent pas toujours celles du champ artistique : par exemple, si la réponse à la demande extérieure apparaît dans le champ artistique comme un principe caractéristique du pôle hétéronome, elle constitue une logique parfaitement légitime dans le groupe professionnel des céramistes, au sein duquel travailler pour le client

fait partie intégrante des pratiques acceptées - voire valorisées.

6. II en existe d'autres, sur lesquelles nous ne nous attarderons pas en raison de la focale adoptée ici : public, intermédiaires culturels, activités artistiques connexes, etc.
Firstly, in concrete terms, heteronomy is visible because quests for autonomy are generally realized through a concomitant logic that consists-not without ambivalence-in seeking material support and symbolic recognition from outside sources of authority and legitimacy. Within the sociology of professions in general, and in the work of Andrew Abbott in particular, protection of a professional territory is made possible by a struggle that unfolds in places of work, relations with the public, and interactions with the state. Thus, this perspective highlights the roles of various "audiences" which are themselves not united (colleagues, the public, the state) in the dynamic process of constituting a professional territory (Abbott 2003). I will focus on certain segments of the field of powerministerial administrations and judicial authorities - that are central to the quest for autonomy of the professional group I am studying here. ${ }^{6}$ Secondly, heteronomy becomes manifest when principles directly threaten the norms of the group. Whereas Bourdieusian sociology designates heteronomy by reference to the bodies of power-in particular, economic power-that influence a field, in this article, the notion is understood in terms of the object it relates to: either the professional group or the artistic field. This distinction is important, since the logics of ceramists do not always match up with those of the artistic field. For example, while responding to outside demand appears as a principle characteristic of the heteronomous pole within the artistic field, it constitutes a perfectly legitimate logic within the professional group of ceramists, where working for the client is an integral, and valued, accepted practice.

6. Others also exist, but I will not dwell on them since the focus here is on the public sphere, cultural intermediaries, related artistic activities, etc. 
Cette différence entre les logiques du champ artistique et celles du groupe professionnel invite en fait à exposer la configuration intrigante dans laquelle se trouve le groupe professionnel : d'un côté, les logiques constitutives du champ artistique (inspiration, originalité, abstraction, vocation et désintéressement, expression d'une intériorité, auteurisation du travail, non-finalité de l'œuvre, etc.) (Bourdieu 1977, Moulin 1983) demeurent centrales pour les céramistes d'art. De l'autre, ils mobilisent également des principes artisanaux contre lesquels se sont initialement positionnés les agents du champ artistique : importance du savoir-faire et des techniques du métier, extériorité et objectivité des critères d'évaluation, fonctionnalité de l'objet, réponse à la demande extérieure, etc. En un mot, ce métier s'est peu à peu codifié au cours de la seconde moitié du $\mathrm{xx}^{\mathrm{e}}$ siècle $^{7}$ par attraction envers le champ artistique en même temps que par opposition avec son nomos - soit sa loi fondamentale et les principes de divisions qui lui sont caractéristiques. C'est cette forme très particulière et ambiguë d'autonomie du groupe professionnel vis-à-vis du champ artistique que nous proposons d'appréhender dans cet article, en mettant en relation le cas des céramistes d'art avec des notions issues de la théorie bourdieusienne des champs. Parce que la lutte autour du nomos du champ artistique prend forme à ses marges, l'imbrication des logiques d'autonomie et d'hétéronomie au sein de ce groupe professionnel (vis-à-vis du champ artistique) y est particulièrement

visible, générant du même coup des évolutions dans ce dernier.

Les résultats proposés sont issus d'un travail de thèse de doctorat en sciences sociales achevé en 2014 sur les céramistes d'art, reposant essentiellement sur des observations consistant en des

7. En tant que métier d'art, c'est un métier récent puisque avant le milieu du $\mathrm{xx}^{\mathrm{e}}$ siècle, la céramique est avant tout fabriquée de façon semi-industrielle selon un mode de fabrication parcellisé. Voir l'article de Flora Bajard (2014).
This difference between the logics of the artistic field and those of the professional group invites us to explore the intriguing configuration in which the professional group is located: on the one hand, there are logics constitutive of the artistic field (inspiration, originality, abstraction, vocation, economic disinterest, expression of an interiority, signing of works, non-utilitarian products, etc. (Bourdieu 1980, Moulin 1983.) On the other hand, there are artisanal principles that agents of the artistic field are initially positioned against: the importance of know-how and techniques of the trade the externality and objectivity of criteria of evaluation; functionality of the object created; response to outside demand, etc. To put it briefly, this profession gradually became codified in the second half of the twentieth century ${ }^{7}$ by simultaneous attraction towards the artistic field and opposition to its nomos, its fundamental law and the principles of division that characterize it. It is this very particular and ambiguous form of autonomy of the professional group with respect to the artistic field that I propose to examine in this article, by connecting the example of artistic ceramists to notions derived from the Bourdieusian theory of fields. Since the struggle surrounding the nomos of the artistic field takes shape at its margins, the interlinking of logics of autonomy and heteronomy within this professional group (with respect to the artistic field) is especially visible there, at the same time driving developments within the group.

The findings I present here are the result of doctoral research on artistic ceramists that I completed in 2014 , and they are primarily based on observations made during fieldwork carried out where

7. As a craft, this is a recent profession, since before the middle of the twentieth century ceramics were mostly manufactured semi-industrially, using the mode of segmented production. See Flora Bajard's article (2014). 
séjours ou en des moments plus ponctuels d'immersion dans des lieux de vie (villages de céramistes, instants conviviaux à domicile) ou de travail (expositions, rencontres professionnelles, etc.), et sur 62 entretiens semi-directifs : 14 ont été effectués auprès de responsables associatifs et institutionnels, les 48 autres ont été menés avec des céramistes, essentiellement en zone rurale sur différents territoires en France. Parmi les enquêtés interrogés, on compte 30 hommes et 23 femmes installés à différentes périodes (4 dans les années 1950-1960, 23 entre 1970 et 1989, et 22 depuis 1990) exerçant sous divers statuts et dans une pluralité de techniques et de conceptions esthétiques. En plus de l'enquête ethnographique, la recherche s'appuie sur les résultats d'une enquête par questionnaire (218 répondants, soit environ $10 \%$ de la population de professionnels) et sur la documentation professionnelle (archives syndicales, compte-rendu associatifs,

supports de communication, etc.)

La première partie de l'article permet de distinguer l'autonomie du groupe professionnel de l'autonomie du champ pour finalement montrer que ce groupe est soumis à une forme d'autonomisation très particulière, faisant de celui-ci un espace " satellite » du champ artistique. La seconde partie montre que, dans ces conditions, l'autonomisation implique des confrontations répétées à l'hétéronomie, par le recours au droit.

\section{Autonomie des groupes, autonomie des champs : les dépendances d'un groupe professionnel satellite}

L'espace de la céramique d'art, pourtant très autonome, entretient des formes de dépendances et de tensions vis-à-vis du champ artistique : il gravite autour de celui-ci et puise dans son nomos, ceramists live (at ceramists' villages, social gatherings in homes, etc.) and work (exhibitions, professional meetings, etc.) and sixtytwo semi-structured interviews. Some of these interviews were with heads of associations and institutions; the other forty-eight were with ceramists, for the most part living in rural areas in different parts of France. Thirty of those interviewed were men, and twentythree women; they began practising in different periods (four in the 1950s, twenty-three between 1970 and 1989, and twentytwo after 1990) and under various professional categories, using a variety of techniques and aesthetic conceptions. In addition to ethnographic inquiry, the research is also based on the results of a survey (218 respondents, or ten per cent of the population of professional ceramists) as well as on professional documentation (trade union archives, association reports, communications materials, etc.)

The first part of the article will allow us to distinguish the autonomy of the professional group from the autonomy of the field, in order to ultimately demonstrate that this group is subject to a very particular form of autonomization, one that makes this space a "satellite" of the artistic field. The second part will show that in these conditions, autonomization involves repeated confrontations with heteronomy, through recourse to the law and the court system.

\section{Autonomy of Groups, Autonomy of Fields: The Dependences of a Satellite Professional Group}

Although the space of artistic ceramics is highly autonomous, it maintains forms of dependence on and tension with the artistic field: it gravitates around this field and draws on its nomos, 
tout en étant aussi construit contre celui-ci. L'autonomisation de ce groupe professionnel est dès lors le théâtre de la lutte pour le pouvoir de définir les normes et frontières du champ artistique lui-

même.

\subsection{L'apparition de la céramique d'art et ses racines} dans le champ artistique

Avant le milieu du $x x^{e}$ siècle, la céramique « artistique » n'existe pas en tant qu'activité collective spécifique constituée autour d'un corpus de normes partagées. Le métier a été « inventé » au milieu $\mathrm{du} \mathrm{XX}^{\mathrm{e}}$ siècle, lorsqu'une première génération de créateurs - pour beaucoup issus des écoles d'art et dotés de dispositions cultivées décide de " faire de l'art » avec l'argile (Bajard 2014). Autrement dit, c'est l'artification - soit la " transformation de non-art en art " (Heinich \& Shapiro 2012) - de pratiques professionnelles antérieures (production de céramique enusines, ateliersfamiliauxetmanufactures de manière industrielle ou semi-industrielle) qui a donné naissance à ce nouveau groupe professionnel en le différenciant de ces autres activités. Dès la fin des années 1940, des normes professionnelles techniques, esthétiques et éthiques ont progressivement été définies, et à partir des années 1960 surtout, les codes de la céramique d'art s'ancrent institutionnellement et s'objectivent dans des structures, objets, et symboles : enseignements et formation d'étudiant·e.s en céramique, chambre syndicale (Ateliers d'art de France $[\mathrm{AAF}])^{8}$, création de réseaux d'échanges d'expériences et de savoirs (rencontres, marchés et événements commerciaux,

8. La chambre syndicale a une histoire beaucoup plus ancienne, mais réoriente son action vers les artisans d'art à partir de 1949 ; voir l'ouvrage d'Anne Jourdain (2014). Si elle inclut l'ensemble des métiers d'art, elle est historiquement liée à la céramique et les céramistes constituent d'ailleurs une part importante des adhérent·e.s qui formaient, en 2010, un quart des effectifs selon cette organisation. Dans notre enquête, près d'un tiers (32\%) des enquêté $\cdot e \cdot s$ par questionnaire en étaient adhérent $\cdot e \cdot s$. while at the same time being constructed in opposition to it. The autonomization of this professional group thus becomes the site of the struggle over the power to define the norms and boundaries of the artistic field itself.

\section{1 The Creation of Artistic Ceramics and its Roots in the Artistic Field.}

Prior to the middle of the twentieth century, "artistic" ceramics did not exist as a specific collective activity constructed around a body of shared norms. The profession was "invented" in the midtwentie $^{\text {th }}$ century, when a first generation of creators - for the most part, people who had gone to art school and were equipped with what Bourdieu calls "cultivated disposition"-decided to "make art" out of clay (Bajard 2014). In other words, it was the "artifaction"-that is, the "transformation of non-art into art" (Heinich \& Shapiro 2012) of earlier professional practices (production of ceramics in factories, family workshops, and industrial or semi-industrial manufacturing) that gave birth to this new professional group by distinguishing it from those other activities. Beginning in the late 1940s, technical, aesthetic, and ethical professional norms were gradually defined and, especially from the 1960s, the codes of artistic ceramics became anchored in institutions and were made objective in structures, objects, and symbols: there were specific classes and training for students of ceramics, a trade association (Ateliers d'art de France $[\mathrm{AAF}]^{8}$ ), networks for exchanging experience and knowledge (meetings, markets, and commercial or festive events),

8. This trade association has a much older history, but beginning in 1949, it redirected its actions towards artistic craftspeople; see Anne jourdain's book (Jourdain 2014). Though it includes all the craft professions, it is historically connected to ceramics and ceramists make up a significant portion of its members - in 2010, they were a quarter of its active members. In my study, almost a third (32\%) of those surveyed by questionnaire were members. 
festivals), supports éditoriaux (livres, revues), et symboles (récompenses et prix). Dans les années 1980 et 1990 apparaissent des associations professionnelles (dont 20 sont réunies dans une union d'associations [Collectif national des céramistes], regroupant ainsi environ 750 ateliers), et même un système de solidarité face aux risques de la vie. Les associations sont le premier type de structure auquel les céramistes adhèrent devant AAF et d'autres associations de créateurs, et à travers ces instances à la fois représentatives du groupe à l'extérieur, et régulatrices de celui-ci en interne, le groupe est fortement auto-organisé. Enfin, les normes professionnelles sont objectivées dans un ensemble d'éléments matériels mais aussi à l'état incorporé, formant ainsi une véritable culture professionnelle aux effets sociaux puissants : il existe par exemple un « idiome corporatif » traduisant la cohésion interne de ce groupe, de même que ces professionnels se rattachent à un " nous ", c'est-à-dire à identité collective forgée autour de valeurs éthiques (solidarité, convivialité, équité, humilité) qu'ils conçoivent comme distinctives et caractéristiques du groupe. Ainsi, à travers ce corpus de pratiques, de représentations et d'éléments matériels, l'activité est devenue une véritable " communauté artistique " distincte des autres métiers et de l'amateurisme parce qu'elle s'est dotée de codes et de " compétences propres ", avec un « consensus sur la nature et les spécificités de cette compétence » (Moulin 1992 : 256)

Sur le plan historique comme du point de vue de l'activité de travail aujourd'hui, la céramique d'art ne peut donc se comprendre indépendamment de cet espace plus large qu'est le champ artistique. D'abord, les céramistes, et plus particulièrement toute une frange en sont partie intégrante : le métier a été fondé par des créateurs trices issu.e.s des mondes de l'art (voir supra) et il est toujours aujourd'hui peuplé par des individus qui évoluent dans certains des espaces centraux du champ artistique (galeries, salons d'art contemporain...). Par ailleurs, plusieurs principes liés au pôle le plus autonome written material (books, journals), and symbols (awards and prizes). In the 1980s and 1990s, professional associations were created (twenty of which are grouped together in the Collectif national des céramistes, thus bringing together around 750 workshops), and even a support system to help ceramists deal with risks and challenges. Professional associations are the most common type of structure to which ceramists belong, followed by the AAF and other creators' associations, and through these bodies, which both represent the group to the outside world and regulate it internally, the group is highly self-organized. Finally, professional norms are made concrete through a set of material as well as immaterial elements, thus forming a true professional culture with powerful social effects. For example, there is a trade dialect' that expresses the group's internal cohesion, and these professionals consider themselves part of a "we," that is, a collective identity forged around ethical values (solidarity, conviviality, equity, and humility) that they see as distinctive and characteristic of the group. Thus, through this body of practices, representations, and material elements, the craft of ceramist has given rise to a true "artistic community" distinct from other professions and amateurs because it has its own codes and "specific skills," as well as a "consensus about the nature and particularities of this skill" (Moulin 1992: 256).

Neither the history nor the current situation of artistic ceramists can be understood independently from the larger space of the artistic field. First, ceramists - and one segment of them in particularare an integral part of this field: the profession was founded by creators who came from the art world (see above), and it still includes people who develop their craft in spaces central to the artistic field (galleries, contemporary art fairs, etc.). Moreover, several principles connected to the most autonomous pole of the artistic field constitute an effective resource within artistic 
du champ artistique constituent une ressource efficiente dans la céramique d'art. La rhétorique professionnelle officielle consiste en effet à mettre à distance " la loi générale » (Bourdieu 2015 : 599), à savoir l'intérêt économique (on fait ce métier par vocation), mais aussi les instances du champ du pouvoir qui statuent sur la professionnalité artistique, formes de « consécration institutionnalisée accordée par un pouvoir agissant dans le champ mais très liée à des pouvoirs externes au champ » (Bourdieu 2015 : 603). Aussi, avoir des revenus très importants ou des gratifications remises par les organes déconcentrés des ministères de la Culture ou de l'Artisanat (par exemple, les «Titre de maître d'art » décernés par le ministère de l'Artisanat) ne constitue pas, pour les céramistes, un gage ultime de professionnalisme.

De plus, la fréquentation de certains espaces artistiques et culturels est générative de ressources au sein du groupe : concrètement certain $\cdot e \cdot s$ céramistes se positionnent de manière particulièrement réussie au sein de l'espace professionnel en s'appropriant des pratiques extérieures telles que l'art contemporain, le design. De même, les principaux prix et distinctions de la céramique d'art sont par exemple décernés à des professionnel-le·s, généralement issu.e.s de la nouvelle génération, qui revendiquent une formation mais aussi des sources d'inspiration et des pratiques empruntant aux arts plastiques, au design ou à l'art contemporain ${ }^{9}$. Ainsi, la frange la plus artifiée au sein du groupe professionnel s'ancre clairement, par des références esthétiques, un discours, mais aussi des pratiques commerciales, dans le champ artistique, voire au pôle où se concentre son capital spécifique.

9. Sur le rôle de céramistes inscrit·e·s dans le pôle le plus artistique de la céramique comme vecteurs d'évolution du groupe (et sur les propriétés sociales de ces professionnels), voir le livre de Flora Bajard (2018a). ceramics. Indeed, the official professional rhetoric of the group consists in eschewing the "general law" (Bourdieu 2015a: 599) of economic interest (the work is a calling or a vocation), as well as the authorities in the field of power that decide on artistic professionalism, forms of "institutionalized consecration granted by a power acting in the field but strongly connected to powers outside of the field" (Bourdieu 2015a: 603). Thus, having very high earnings or receiving recognition from the regional offices of the ministries of culture or crafts (for example, the title of "Master of Art" awarded by the Ministry of Crafts) does not represent the ultimate mark of professionalism for artistic ceramists.

In addition, resources are generated within the group by members frequenting certain artistic and cultural spaces: for example, some ceramists are particularly successful in positioning themselves within the professional space by appropriating external practices such as contemporary art or design. Similarly, the main prizes and distinctions for artistic ceramists are awarded to professionals, usually of the younger generation, who lay claim to training, inspiration, and practices borrowed from the plastic arts, design, or contemporary art. ${ }^{9}$ Thus, through aesthetic references, discourse, and commercial practices, the most "ratified" segment of this professional group is clearly embedded in the artistic field, at the pole where its specific capital is concentrated.

9. For more on the role of ceramists at the most artistic pole of the field of ceramics as vectors of the group's evolution (and on the social characteristics of these professionals), see Flora Bajard's book (Bajard 2018a). 
D'ailleurs, cette inscription dans le champ artistique s'observe aussi par la négative, c'est-à-dire par des formes de distinction (la distinction n'étant nécessaire que lorsqu'il y a proximité, réelle ou supposée) : ils·elles se différencient ainsi fortement des designers, plasticien'ne's et autres acteurs'rices de l'art contemporain, pour qui l'argile peut être un médium utilisé ponctuellement parmi d'autres lors de performances ou installations éphémères, par exemple. Au contraire, les céramistes mettent un point d'honneur à utiliser l'argile comme matériau à part entière, impliquant notamment la maîtrise des techniques (parfois très complexes) de façonnage, de cuissons, ou encore la composition chimique des lustres et émaux. Les céramistes ne sont donc pas hors du champ artistique, mais dans le même temps, ils'elles ne sont pas non plus reconnu.e.s comme partie intégrante de celui-ci, car tout en aspirant à " en être ", nous verrons qu'ils·elles refusent aussi d'être tout à fait soumis·es à ses

lois spécifiques.

\subsection{Les céramistes d'art au cœur du hiatus} entre l'art et l'artisanat

Le statut d'artiste et la définition juridique de l'œuvre d'art en France reposent sur un faisceau d'indices, comme la non-utilité et nonfinalité de l'œuvre d'art (qui est « porteuse de sa propre finalité », c'est-à-dire n'a pour finalité que sa non-finalité) ${ }^{10}$, l'originalité ${ }^{11}$, et enfin, l'unicité, signature et entière exécution par l'individu qui sont

10. À partir de 1982, l'Institut national de la statistique et des études économiques (Insee) indiquait encore que les artistes sont ceux qui, « dans le domaine des arts plastiques ou graphiques, créent une œuvre originale, susceptible de procurer par sa contemplation un plaisir esthétique et reconnue comme porteuse de sa propre finalité » (Moulin 1992 : 267).

11. Lettre ministérielle du 7 avril 1981 relative aux critères d'affiliation au régime de sécurité sociale des artistes auteurs d'œuvres graphiques et plastiques (Annexe à la circulaire du 16 février 011 relative aux revenus tirés d'activités artistiques relevant de l'article $L$ 382-3 du Code de la Sécurité sociale).
Belonging to the artistic field can also be observed negatively, in forms of distinction (distinction is only necessary when there is real or supposed proximity): artistic ceramists strongly distinguish themselves from designers, visual artists, and other contemporary artists who might occasionally use clay as one medium among others in performances or temporary installations, for example. On the other hand, they make it a point of honour to use clay as an integral part of their activity, which involves mastering (sometimes very complex) techniques of shaping and firing as well as the chemical composition of glazes and enamels. Thus, ceramists are not outside the artistic field, but they are also not recognized as fully belonging to it, for even as they aspire "to belong," we shall see that they also refuse to be completely subjected to its specific laws.

\subsection{Artistic Ceramists: Between Art and Craft}

In France, the status of artist and the legal definition of a work of art are based on a set of markers that include the non-utility and nonpurposiveness of works of art (which "contain their own purpose"that is, their only purpose is their non-purpose ${ }^{10}$ ), originality, ${ }^{11}$ and finally, the fact of being unique, signed, and entirely created by

10. Beginning in 1982, the National Institute of Statistics and Economic Studies (Insee) indicated that artists are those who "in the domain of plastic or graphic arts create unique works that, when contemplated, provide aesthetic pleasure and are recognized as containing within themselves their own purpose" (Moulin 1992: 267)

11. Ministerial letter of 7 April 1981 regarding criteria for affiliation with the social security regime for graphic and plastic artist-authors (Annexe to the 16 February 2011 circular regarding revenue from artistic activity covered by article L $382-3$ of the Social Security Code). 
considérées comme les composantes de l'originalité ${ }^{12}$. Ce sont ces critères qui sont mobilisés par les Directions régionales des affaires culturelles (Drac) ou la Maison des artistes (MdA), pour statuer sur l'octroi d'aides à la création ou sur l'attribution du statut d'artiste. Or, en tant qu'institutions déconcentrées chargées de mettre en œuvre la politique du ministère de la Culture à l'échelon régional pour les premières, ou organisme en charge de la gestion du statut et des droits à la protection sociale des artistes en France pour la seconde, ces deux institutions représentent des sources d'autorité centrales

en matière artistique et culturelle.

C'est là une tension très importante, car si le groupe professionnel reproduit certains aspects du capital spécifique au champ artistique, et si la très grande majorité des enquêté $e \cdot s$ se considèrent extérieurs à l'artisanat dans ses formes les plus classiques (métiers de bouche, du bâtiment) ${ }^{13}$, l'artification totale des pratiques professionnelles ne représente pas un but ultime et unique. Les logiques artisanales constituent une norme éthique que partagent en général (au moins publiquement) même ceux qui ne font que des pièces uniques et de la sculpture, ou exercent sous le statut d'artiste. De plus, toute une frange de céramistes fondent leur grandeur professionnelle sur ce que nous pourrions appeler le plus noble de l'artisanat : ces pratiques professionnelles reposent alors souvent sur une politisation de l'activité, visant à proposer une « qualité de vie » pour la clientèle (faire des choses à la fois « belles et utiles », pour « le quotidien des

12. «Exemplaires uniques de céramique, entièrement exécutés par l'artiste et signés par lui »: Code général des impôts, annexe 3 - Article $98 \mathrm{~A}$.

13. Il est arrivé qu'un enquêté se compare à « un très bon plombier » lors d'un entretien, mais il s'agissait alors de mettre en valeur la dimension artisanale de son métier dans ce qu'elle a de plus valorisant selon lui, à savoir une utilité sociale. an individual, which are considered components of originality. ${ }^{12}$ These criteria are used by the Directions régionales des affaires culturelles (DRAC) and the Maison des artistes (MdA) to determine who receives grants or the status of artist. The former, as regional institutions charged with implementing the policies of the culture ministry at the local level, and the latter, an organization in charge of administering artists' status and rights to social security in France, both represent central sources of authority on art and culture.

This tension is very important, for although this professional group reproduces certain aspects of the capital specific to the artistic field, and although a large majority of those surveyed consider themselves to be outside of traditional forms of craft (the food or building professions, for example ${ }^{13}$ ), the total "ratification" of professional practices does not represent an ultimate or unique goal. Artisanal logics constitute an ethical norm shared (at least publicly) by most ceramists, including those who only make unique pieces or sculptures, or who have the status of artist. In addition, there is a whole segment of ceramists who base their professional value on what might be considered the most noble aspect of the craft: a politicization of their work, which aims to provide clients with "quality of life" (making "beautiful and useful" things for "people's everyday lives"14); thus, responding

12. "Unique ceramic pieces, entirely made by the artist and signed by him or her." General Tax Code, Appendix 3 - Article 98 A

13. One ceramist surveyed compared himself to "a very good plumber" in an interview, but this was to highlight the artisanal dimension of what he considers to be the most valuable aspect of his work: its social usefulness.

14. This is also why these ceramists refer to a popular aesthetics or an ethics of minimalist ethics, such as do-it-yourself, in opposition to contemporary art, which they associate with economic and cultural elitism. 
gens $")^{14}$ : la réponse à la demande du client est aussi une tâche noble. De manière plus large, l'efficacité économique est un gage de professionnalisme et de sérieux, et, paradoxalement, d'engagement profond dans la vocation. En raison de cette dissonance essentielle entre les normes professionnelles et les normes juridiques sur lesquelles s'appuient des institutions culturelles publiques, la céramique d'art ne saurait donc constituer un sous-champ artistique, "sous-espaces relationnels qui fonctionnent comme des champs en miniature » (Marchetti 2002 : 24). Certes, les dissonances ne sont bien entendus pas exemptes, ni au sein d'un sous-champ, ni entre sous-champs, puisque "les artistes de bords opposés peuvent, à la limite, n'avoir rien en commun que leur participation à la lutte pour l'imposition de définitions opposées de la production littéraire ou artistique » (Bourdieu 1991: 7). Cependant, les céramistes ne cherchent pas ici à imposer et valoriser une partie du capital spécifique au champ artistique face à une autre partie de celui-ci : ils importent une norme en contradiction totale avec l'un des principes constitutifs du nomos du champ artistique, à savoir la fonctionnalité des œuvres. En effet, pour résumer, être un professionnel, et encore davantage être un « grand nom » de la céramique française contemporaine, c'est à la fois se distinguer par une certaine originalité artistique et accorder une importance à l'esthétique, et maîtriser les difficultés et exigences techniques du matériau pour créer des objets pouvant tout à fait remplir une fonction. À ce titre, parce que les normes du groupe impliquent de combiner art et artisanat sans renier l'une de ces composantes, cet espace professionnel ne pourrait pas non plus s'apparenter à un champ faible (Vauchez 2008 : 136 ; Vauchez \& Georgakakis 2015). En tant qu'espace peu unifié, peu institutionnalisé et aux frontières

14. C'est aussi pour cela que ces céramistes se réfèrent à une esthétique populaire ou à une éthique du minimum comme le Do It Yourself, par opposition à l'art contemporain, qu'ils associent à l'élitisme économique et culturel. to client demand is also a noble task. More broadly, economic proficiency is a measure of professionalism and seriousness, and, paradoxically, of deep commitment to the vocation. Because of this fundamental dissonance between professional norms on the one hand and the legal norms that public cultural institutions draw on, artistic ceramics cannot be considered an artistic sub-field, that is, "a relational sub-space that operates as a miniature field" (Marchetti 2002: 24). Of course, there are dissonances within subfields as well as between them, since "artists from opposite sides might even have nothing in common other than their participation in the struggle to impose opposing definitions of literary or artistic production" (Bourdieu 1991: 7). However, ceramists do not seek to impose and valorize one part of the specific capital of the artistic field over and against another part of that capital; rather, they bring in a norm that is in total contradiction to one of the principles constitutive of the nomos of the artistic field-that is, the functionality of their creations. In fact, and to summarize, to be a professional in contemporary French ceramics-and, even more, to be a "big name"-means both setting oneself apart through one's artistic originality and giving importance to aesthetics, and mastering the difficulties and technical requirements of the material in order to create fully functional objects. For this reason, because the group's norms imply combining art and craft without giving up either component, this professional space cannot be related to a weak field (Vauchez 2008:136; Vauchez \& Georgakakis 2015). A weak field is a space that is scarcely unified or institutionalized, and whose boundaries are porous (idem), and it exists at the interstices of historically constituted fields. Its specific capital comprises the capitals proper to the spaces connected to it, and if they are contradictory, they are used strategically depending on who the audience is or what is at stake (Sacriste 2014: 55). Among ceramists, the two types of capital-artistic and artisanal-cannot be separated, and artistic ceramists defend, both individually and 
poreuses (Vauchez 2008 : 136 ; Vauchez \& Georgakakis 2015), un champ faible existe dans les interstices de champs historiquement constitués. Son capital spécifique se compose de capitaux propres à ces espaces connexes, et s'ils sont antinomiques, ils sont alors utilisés de manière stratégique en fonction des auditoires et enjeux (Sacriste 2014 : 55). Or, chez les céramistes, les deux types de capitaux, plutôt artistiques ou plutôt artisanaux, ne sont pas dissociables, et les céramistes défendent, de manière individuelle ou collective, une définition unifiante de la création tendant à gommer la dichotomie entre art et artisanat.

\subsection{Un « espace satellite » du champ artistique}

Ce métier pourrait, certes, être un sous-champ si on emploie la notion de manière plus souple et moyennisante, comme un espace " inclus dans un espace plus vaste et placé sous la domination de celui-ci, mais qui, à certains égards et sous certaines conditions, parvient à se soustraire partiellement à son pouvoir d'imposition " (Dozo 2009). Mais dans ces conditions, la notion ne dit alors plus grand-chose ici des tensions qui traversent cet espace. C'est le même écueil que l'on retrouve avec la notion d'espace hybride, qui contient l'idée de syncrétisme ou de synthèse entre différents espaces ${ }^{15}$, désignant alors le métier par défaut - ni totalement de l'art, ni totalement de l'artisanat. Considérer la céramique d'art comme un sous-champ artistique ou un espace hybride dans une conception moyennisante ne permet donc pas de penser le caractère agonistique des relations entre l'espace professionnel et les champs connexes. Car, c'est là une nuance fondamentale, les céramistes d'art ne se situent pas seulement « entre art et

15. Dans d'autres cas, mais qui ne renvoient alors plus du tout au cas étudié, les espaces hybrides sont des lieux " où se rencontrent et agissent, comme concurrents ou comme partenaires, plusieurs professions et organisations » (Boussard $2015: 365$ ). collectively, a unifying definition of creation that aims to erase the dichotomy between art and craft.

\subsection{A "Satellite Space" of the Artistic Field}

Of course, this profession could be considered a sub-field if we use the concept in a more flexible and approximate way and define it as a space "included in a larger space and under its domination but which, in certain respects and under certain circumstances, succeeds in partially escaping its power of imposition" (Dozo 2009). But then the notion no longer tells us much about the tensions that run through this space. We find the same difficulty with the notion of hybrid space, which contains the idea of syncretism or a synthesis of different spaces, ${ }^{15}$ thus defining the profession negatively: it is neither totally art nor totally craft. Therefore, considering artistic ceramics as an artistic sub-field or as a hybrid space within an approximative conception does not allow us to think through the agonistic nature of the relations between the professional space and the spaces related to it. For-and this is crucial-artistic ceramists do not only situate themselves "between art and craft": some of them (both individuals and the organizations that represent them) struggle against some of the most legitimate and constitutive

15. In other cases, which do not match the example studied here, hybrid spaces are places "where several professions and organizations meet and act as competitors or as partners" (Boussard 2015: 365). 
artisanat »: une partie d'entre eux·elles, à commencer par les individu.e.s et organisations qui les représentent, luttent contre une partie des normes les plus légitimes et constitutives du champ au sein duquel ils.elles cherchent à être reconnu·e.s. Ce faisant, le concept de simili-champ s'applique lui aussi difficilement à cet espace, car tandis que le simili-champ littéraire constitue pour les écrivain'e.s amateurs « cet univers de consolation, doté d'institutions destinées aux aspirants écrivains " (Poliak 2006 : 244-245), les céramistes maîtrisent les règles de la culture légitime et croient en leur légitimité à en être. D'abord, certains enquêtés cherchent à démontrer le caractère artistique de certaines œuvres ou pratiques jugées artisanales par la Drac ou la MdA et à contester les critères de définition de l'œuvre d'art censée être « inutile » ou « sans finalité ». On retrouve ainsi une opposition classique au sein du champ culturel, qui va porter sur la définition de l'artiste légitime et se traduire par la lutte entre deux formes d'art légitime : l'art sans finalité et l'art fonctionnel (Bourdieu 2015 : 631). La seconde forme de critique prend la forme d'une contestation des hiérarchies culturelles donnant à l'art une valeur culturelle supérieure à celle de l'artisanat: les professionnels les plus proches de l'artisanat s'emploient alors à défendre la valeur culturelle de leur travail artisanal et le bien-fondé de sa prise en charge par le ministère de

la Culture.

Le groupe professionnel est donc formé de prétendants à l'entrée ou au maintien dans le champ qui cherchent à subvertir l'une de ses définitions essentielles : la définition de l'art. Dès lors, la notion d'espace " satellite " nous semble pouvoir combiner de manière synchronique ces dimensions d'attraction et d'indépendance. Cet espace professionnel serait en effet une entité attirée par le champ artistique, car apparu par rapport à celui-ci et gravitant désormais autour de lui, bien que doté d'une cohérence interne en partie contradictoire avec celui-ci. norms of the field in which they seek to be recognized. Thus, it is also difficult to apply the concept of simili-field to this space, for whereas for amateur writers the literary simili-field constitutes "a universe of consolation, which provides institutions intended for aspiring writers" (Poliak 2006: 244-245), ceramists master the rules of the legitimate culture and believe they legitimately belong to it. First, some of the ceramists surveyed seek to demonstrate the artistic nature of certain works or practices that the DRAC or the MdA consider artisanal, and to contest the criteria for defining works of art, which are supposed to be "useless" or "purposeless." Here we find a traditional opposition within the cultural field, one that impacts the definition of a legitimate artist and is expressed in the struggle between two forms of legitimate art: art with no purpose and functional art (Bourdieu 2015a: 631). Second, some ceramists contest the cultural hierarchies that ascribe higher cultural value to art than to craft: professionals who are closest to the craft world try to defend the cultural value of their artisanal work and to justify it being overseen by the ministry of culture.

We see that the professional group is made up of those who seek to enter or uphold the field and to subvert one of its essential definitions: the definition of art. The notion of a "satellite" space seems to be capable of synchronically combining these dimensions of attraction and independence. On this reading, the professional space of ceramists is attracted by the artistic field, since it was created in relation to it and continues to gravitate around it, even though this space has its own internal coherence that partially contradicts that field. 


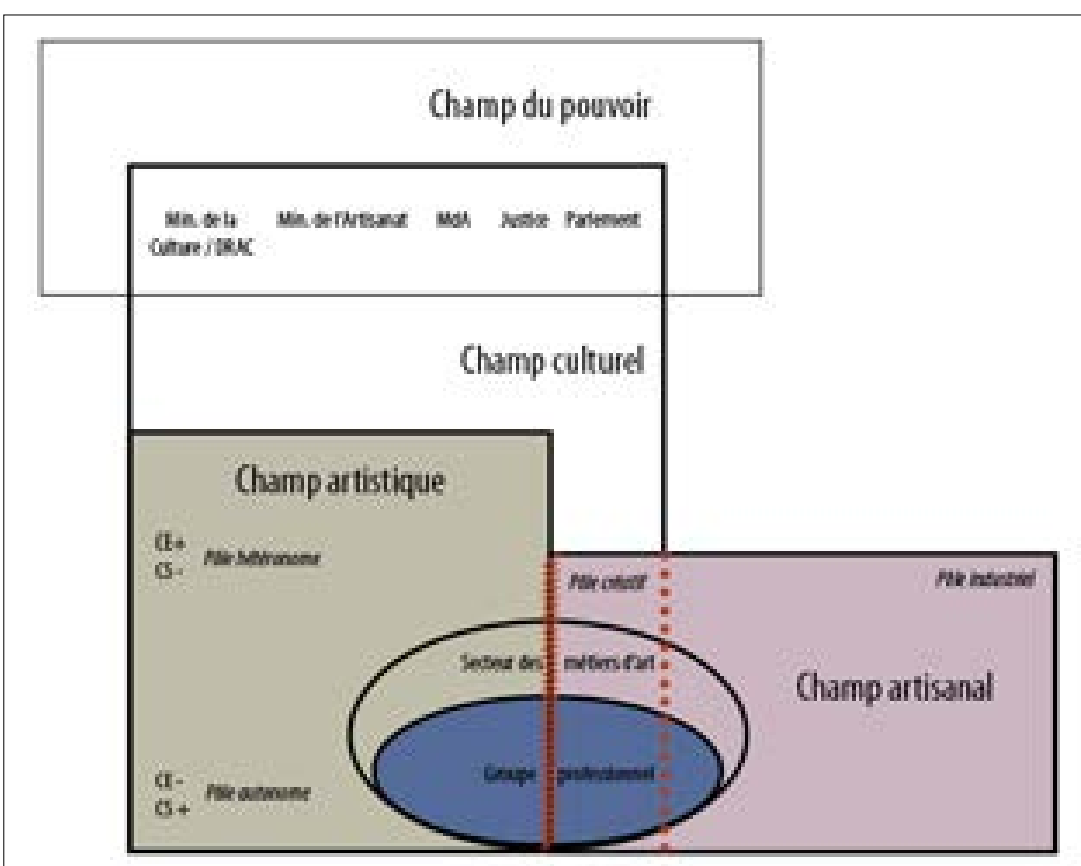

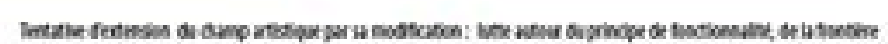

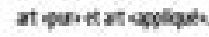

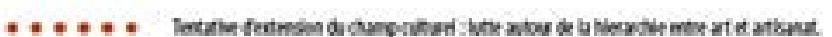

$$
\text { Fig. } 2
$$

Deux logiques de transformation des champs artistique et culturel promues par les céramistes.

$$
\text { Source : Flora Bajard. }
$$

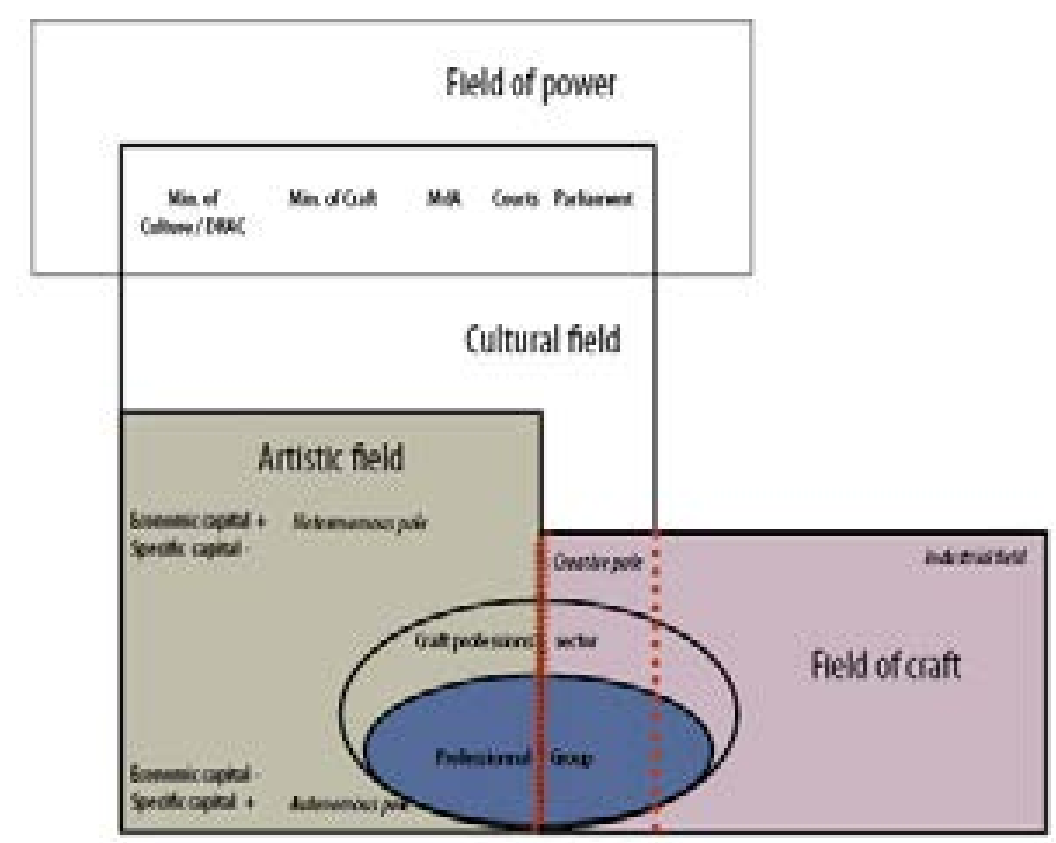

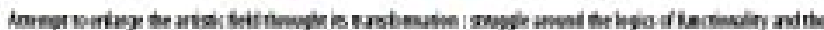

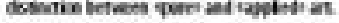

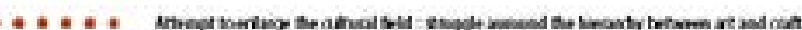

$$
\text { Fig. } 2
$$

Two logics of transformation of the artistic and cultural fields promoted by ceramists. Source: Flora Bajard. 


\section{Le recours au droit comme instrument d'hétéronomie négociée : la mise en forme de l'autonomie du groupe par l'État}

Les logiques d'autonomie et d'hétéronomie sont en fait intriquées : les confrontations à l'hétéronomie prennent des formes diverses (entrevues informelles, lettres, demandes de subventions, etc.) mais les plus visibles et performatives sur les normes professionnelles sont le recours au droit. Celles-ci visent à infléchir la définition juridique et institutionnelle de l'art en France, qui en l'occurrence recoupe les règles du champ artistique ${ }^{16}$. Ce faisant, chacune de ces confrontations constitue un pari réalisé par le groupe professionnel sur sa capacité à négocier une hétéronomie ajustée à ses conceptions de l'activité, et cela passe par une tentative

d'élargissement des frontières du champ artistique et culturel.

La méfiance à l'égard des institutions publiques se manifeste, chez les céramistes, par une accusation d'instrumentalisation folklorique des métiers d'art par les institutions liées au ministère de l'Artisanat, et la critique du mépris que les professionnel-le.s ressentent de la part des institutions liées au domaine artistique. Cependant, cette posture s'accompagne d'une quête de reconnaissance, qui se traduit par la contestation individuelle de certaines décisions de radiations ou de non-admission à la MdA, et par la lutte - également individuelle - pour l'obtention de subventions de la part de Drac. Ces revendications portent d'ailleurs généralement plus sur des enjeux symboliques que sur les bénéfices matériels associés au statut d'artiste - plus avantageux que les autres statuts de travailleur indépendant en termes de cotisations sociales, par exemple - ou

16. Sur le champ du pouvoir (ou bureaucratico-politique) comme « métachamp » liée à la constitution d'autres champs autonomes, voir par exemple l'ouvrage de Pierre Bourdieu (2012).

\section{The Law as a Tool of Negotiated Heteronomy: How the State Shapes the Autonomy of the Group}

The logics of autonomy and heteronomy are in fact intertwined: there are various forms of encounter with heteronomy (informal interviews, letters, requests for funding, etc.), but the most visible form, with the greatest effect on professional norms, is the use of the law and the courts. The goal is to influence the legal and institutional definition of art in France, which matches up with the rules of the field of art. ${ }^{16}$ Thus, each of these counters constitutes a bet made by the professional group on its ability to negotiate a heteronomy adjusted to its understanding of its activity, and this takes place through an attempt to extend the boundaries of the artistic and cultural field.

Among ceramists, distrust of public institutions is expressed in the accusation that the institutions linked to the ministry of crafts downgrade craftwork to folklore, and in criticism of the contempt that professionals experience from institutions connected to the artistic domain. However, this attitude goes along with a quest for recognition, which is expressed in individual challenges to certain decisions by the MdA, to remove or to not admit certain professionals, and by the struggle-also individual - to obtain grants from the DRAC. These claims generally have more to do with symbolic stakes than with the material benefits associated with the status of artist-which is more advantageous than other categories of independent worker in terms of social security contributions, for example-or the financial support that these institutions might provide. This attachment

16. For more on the field of power (or the bureaucratic-political field) as a "meta-field" connected to the constitution of other autonomous fields, see for example Pierre Bourdieu's book (Bourdieu 2015b). 
au soutien financier que pourraient apporter ces institutions. Cet attachement aux enjeux symboliques tient beaucoup aux propriétés sociales des céramistes : bien dotés en capitaux culturels et scolaires, ces professionnel·le·s s'éloignent en grande majorité d'un destin social associé à la réussite économique ou symbolique. Au contraire, ils·elles construisent leur trajectoire en s'attachant à la dimension artisanale de leur métier, qu'ils·elles associent à la modestie et à I'humilité du style de vie et des pratiques ainsi recherchés. Le recours au droit est donc le fruit d'un rapport complexe et ambigu à la culture légitime d'individu.e.s globalement familiarisée.e.s à celle-ci, mais qui en sont en partie exclu·e·s du fait de l'exercice de leur activité professionnelle, nourrissant un fort sentiment d'injustice, d'humiliation et, au fond, de déclassement ${ }^{17}$. Pour mettre en acte cette critique, la chambre syndicale AAF ainsi que quelques céramistes œuvrant individuellement ont recours au droit. Cela passe, d'une part, par la judiciarisation de ce qui fait problème pour eux (procès), d'autre part, par sa juridicisation (mobilisation des normes juridiques existantes et tentatives de transformation de celles-ci) (Pélisse 2009).

\subsection{La judiciarisation : les procès contre la Maison des artistes}

En désignant les artistes (et en les distinguant de ceux qui ne le sont pas), la MdA délivre « ce qui tient lieu, bien que le terme soit évité avec soin par le texte de loi, de certificat de professionnalité " (Moulin 1992 : 394). Or, l'entrée dans les mondes de l'art s'effectue par la soumission aux critères du champ artistique : "les exclus ne parviennent à se faire reconnaître comme créateurs qu'en se soumettant à la définition de l'œuvre comme "originale" et "inutile", en entrant dans les réseaux et en exposant dans les lieux adéquats

17. Sur la position d'intermédiaires ou de marginaux sécants des céramistes dans la stratification sociale, et leurs trajectoires caractérisées par une forte mobilité, voir l'ouvrage de Flora Bajard (2018a) to symbolic stakes has much to do with the social properties of ceramists: well endowed with cultural and academic capital, these professionals, for the most part, keep their distance from a social trajectory that would lead to economic or symbolic success. On the contrary, they determine their trajectory by focusing on the artisanal dimension of their work, which they associate with modesty and a humble lifestyle and practices. The decision to turn to make use of the legal system is thus the result of a complex and ambiguous relationship between the legitimate culture and individuals who are familiar with it but are partially excluded from it as a result of their professional activity, which feeds a strong feeling of injustice, humiliation, and at bottom, a lowered status. ${ }^{17}$ In order to act on this criticism, the trade association AAF as well as some independent ceramists have turned to the courts. This involves, on the one hand, judicialization of the problems they face (court cases), and, on the other hand, juridification (mobilisation of existing legal norms and attempts to transform them) (Pélisse 2009).

\subsection{Judicialization: Cases Against the Maison des Artistes}

By determining who is an artist (and by distinguishing those who are from those who are not), the MdA delivers "something that serves as a professional certificate, even though the text of the law carefully avoids this term" (Moulin 1992: 394). Entry into the art world is achieved by submitting to the criteria of the artistic field: "those who are excluded do not succeed in being recognized as creators unless they submit to the definition of the work of art as 'original' and 'useless,' and by entering networks and exhibiting in adequate

17. For more on the position ceramists as intermediaries or influential outsiders in social stratification, and their trajectories, which are characterized by a high level of mobility, see Flora Bajard's book (2018a). 
(Becker, 1978) » (Moulin 1992 : 267). Pour cette raison, si presque un tiers $(28 \%)$ des enquêté.e.s par questionnaire exercent sous le statut d'artiste, ils·elles sont nombreux.ses à avoir joué avec le règlement de la MdA pour y être affiliée.e.s, par exemple en ne présentant que des pièces sculpturales ou plastiques, en occultant la dimension utilitaire de leurs créations, ou encore en présentant des dessins ou peintures et en étant officiellement inscrite.e s comme peintres. À l'inverse, d'autres démarches entreprises par certain·e.s céramistes se caractérisent par le conflit : à partir des années 1980, après avoir été refusé.e.s ou radié.e.s en raison du caractère « artisanal » de leurs créations, des professionnel·le.s ont engagé des procès à titre individuel contre la MdA ${ }^{18}$. Le premier procès, en 1979 , a duré quatre ans, depuis le jugement rendu par la Commission de première instance de la Sécurité sociale, jusqu'à différents renvois devant une cour d'appel et la Cour de cassation. C'est sur la définition de l'originalité d'objets pourtant jugés fonctionnels/utilitaires qu'ont porté les dissensions : le critère d'utilité viendrait contrecarrer le critère d'originalité. C'est pour ce même motif qu'un autre céramiste s'est vu refuser l'affiliation à ce régime de Sécurité sociale en 1983 : le tribunal a exprimé que «les œuvres céramiques à des fins fonctionnelles n'étaient pas des œuvres d'art ${ }^{19}$ ", et émis un avis selon lequel ce céramiste aurait " une activité de métier d'art ${ }^{20}$ ». Quelque temps après, d'autres juges ont à l'inverse souligné que la notion d'originalité ne peut dépendre que des critères objectifs du Code des impôts : unicité, exécution à la main, signature. Plus

18. Nous remercions les céramistes évoqué·e·s dans cette section, qui se reconnaîtront, pour la transmission des documents liés à leur affiliation ou aux recours judiciaires autour de celle-ci.

19. Selon les termes employés dans la lettre adressée par la Maison des artistes à ce céramiste ; informations mentionnées dans l'article de La Revue de la céramique et du verre, $\mathrm{n}^{\circ} 17,1984$.

20. Recours gracieux formulé par ce céramiste auprès de la Caisse régionale d'assurance maladie (décembre 1983). spaces (Becker 1978)" (Moulin 1992: 267). This explains why, of the 28 per cent of survey respondents who practise as artists, many have fiddled MdA regulations in order to be affiliated with it-for example, by only presenting sculptural or plastic pieces, by hiding the utilitarian aspect of their creations, or by presenting drawings or paintings and being officially registered as painters. Other tactics used by some ceramists are, on the contrary, characterized by conflict: beginning in the 1980s, after having been rejected or banned on the grounds of the "artisanal" nature of their works, some professionals launched individual cases against the MdA. ${ }^{18}$ The first case, in 1979, lasted four years, from the decision delivered by the Social Security Commission, the court of first instance, down through various appeals before an appeals court and the Cour de cassation. The disputes had to do with the definition of the originality of objects judged to be functional or utilitarian: the criterion of utility came to be seen as counter to the criterion of originality. This was also the grounds for rejecting another ceramist's affiliation with this social security regime in 1983: the court wrote that "ceramic works with functional purposes were not works of art," ${ }^{19}$ and issued an opinion stating that this ceramist practised "a craft profession." ${ }^{20}$ Some time later, other judges emphasized that, on the contrary, the notion of originality can only depend on the objective criteria established in the Tax Code: the work must be unique, hand-made, and signed. More recently, in 2006, another ceramist was banned from the MdA a year and a half after being admitted, on the grounds that he too

18. I would like to thank the ceramists mentioned in this section for sharing documents with me related to their membership or the legal processes surrounding it.

19. These are the terms used in the letter from the Maison des artistes to this ceramist; the information is cited in the article from La Revue de la céramique et du verre, 17, 1984.

20. Appeal for reconsideration made by this ceramist to the Regional Health Insurance Office (December 1983). 
récemment, en 2006, à la suite de sa radiation un an et demi après son affiliation à la Maison des artistes sous le motif qu'il fait un " métier d'art ", un autre céramiste engage un procès contre la MdA. Le tribunal souligne que les articles en vigueur auxquels doit se référer la $\mathrm{MdA}$ « ne font pas référence au caractère utilitaire ou non des créations » et demande donc la réaffiliation immédiate du professionnel à l'organisme de Sécurité sociale. Ainsi, dans les cas qui ont été portés à notre connaissance, les instances judiciaires ont chaque fois donné raison aux céramistes à l'instar du verdict suivant émis en 2009, précisant que le fait que les créations de $X$ « prennent la forme d'objets utilitaires ne leur retire pas nécessairement le caractère d'œuvres originales en exemplaire unique, entièrement exécutées de la main de l'artiste et signées par lui ${ }^{21}$ ».

C'est donc chaque fois pour faire reconnaître la légitimité à être artiste tout en faisant de la céramique et à « exercer leur art sur un pot ", comme le mentionne un article paru dans La Revue de la céramique et du verre ${ }^{22}$, que se sont battu·e.s ces professionnel.le·s. Ces procédures judiciaires - nous en avons recensé au moins cinq entre 1979 et 2009 - matérialisent ainsi judiciairement l'une des deux formes de positionnement émis dans l'espace professionnel vis-àvis des institutions culturelles : la tentative de démonstration de la nature artistique d'un travail utilitaire, et par extension, la contestation des critères classiques de partition entre art et artisanat. Ces procès individuels témoignent cependant des phénomènes de mobilité collective du métier, les bénéfices attendus étant avant tout une requalification symbolique du travail et du statut de ces créateurs faisant jurisprudence. D'ailleurs, ces combats engagés pour obtenir ou conserver l'affiliation à la MdA furent publicisés et diffusés au

21. Extrait du jugement rendu le 15 mai 2009 par le Tribunal des affaires de sécurité sociale d'une ville de province.

22. La Revue de la céramique et du verre, $\mathrm{n}^{\circ} 17,1984$. practised a "craft profession;" he then opened proceedings against the organization. The court pointed out that the laws to which the MdA was required to refer "do not refer to whether creations are utilitarian or not," and thus required the immediate re-admittance of the professional to the social security body. Thus, in each of the cases I studied, judicial authorities vindicated ceramists, as in the following verdict delivered in 2009 , which specified that the fact that X's works "take the form of useful objects does not necessarily mean that they are not original, unique, entirely hand-made by the artist, and signed by him." ${ }^{21}$

Thus, in each case, professional ceramists fought to have their legitimacy as artists who work with clay and "practise their art on pots"-as one article published in La Revue de la céramique et $d u$ verre $^{22}$ puts it-recognized. These legal proceedingscounted at least five between 1979 and 2009-represent one form of positioning vis-à-vis cultural institutions that emerges from the professional space: the attempt to demonstrate the artistic nature of utilitarian work, and, by extension, to challenge the classic criteria separating art from craft. These individual cases also demonstrate phenomena of collective mobility within the profession: the benefits in question amount above all to the symbolic requalification of the work and status of these creators, which sets a precedent. Moreover, these fights to obtain or maintain affiliation with the MdA were publicized and circulated within the professional group, both through oral history and informal

21. Excerpt from the ruling made on 15 May 2009 by the Social Security Court of a provincial city.

22. La Revue de la céramique et du verre, 17, 1984. 
sein du groupe professionnel, tant par l'histoire orale et les récits informels - audibles par exemple lors des événements festifs ou commerciaux - transmis au sein du métier que dans La Revue de la céramique et du verre, par exemple. L'opposition commune aux principes de vision et de division du monde sur l'art et l'artisanat est en effet partagée par de très nombreux-ses céramistes et constitue une rhétorique professionnelle officielle, alors même que tous les céramistes n'ont pas eu à subir personnellement ce qu'ils et elles présentent comme des affronts.

\subsection{La juridicisation de la cause :} transformer les normes existantes

Dès les années 1970, des propositions autour d'un statut d'artisan d'art « créateur » ont émergé pour pallier la non-reconnaissance par les chambres des métiers de la spécificité des artisans d'art ainsi que les difficultés d'accès à la MdA. Cherchant à rapprocher l'activité des artisans d'art de l'activité artistique, les promoteurs de ce statut, en particulier la chambre syndicale (AAF) et la Fédération nationale des ateliers d'art, ne verront pas leur revendication aboutir ${ }^{23}$. Vingt ans après l'échec du projet de statut d'artisan d'art, cette idée est réhabilitée par AAF. En 2013, le président d'AAF et la directrice des opérations alors en fonction soumettent, aidés par des expert·e.s en droit social, droit des affaires et des fiscalistes, une note de synthèse au cabinet du premier ministre du gouvernement français de l'époque, Jean-Marc Ayrault. Dans celle-ci, ils s'emploient à montrer la dimension créative de l'artisanat d'art et à défendre l'idée que « l'artisan d'art est le créateur d'œuvres originales « portant l'empreinte de la personnalité de son auteur " " (Audugé 2013 : 2). Pour cela, ils s'appuient notamment sur le Code de la propriété

23. Sur les tenants de cet échec, établi en 1990, voir l'ouvrage d'Anne Jourdain (2014). narratives-for example, at festive or commercial events-and in La Revue de la céramique et du verre. Many ceramists share an opposition to the principles of vision and division that define the world of art and craft, although not all ceramists have had to personally face what they perceive as affronts.

\subsection{The Juridification of the Cause: Transforming Existing Norms}

From in the 1970s, proposals began to emerge for a new status, that of the "creative" artisan d'art, in order to make up for The Chambers of Trades and Crafts ${ }^{23}$ non-recognition of the particularity of artisans d'art [artistic craftspeople] and their difficulty in accessing the MdA. Those who advocated for this status-in particular the trade association AAF and the Fédération nationale des ateliers d'art-in order to bring together the activities of artisans d'art and of artists, were not successful. ${ }^{24}$ Twenty years later, the idea was again taken up by the AAF. In 2013, the president of the AAF and its director of operations, with the assistance of experts in social security law, business law, and taxes, submitted a summary note to the cabinet of the French prime minister at the time, Jean-Marc Ayrault. In it, they tried to show the creative dimension of artistic craftwork and to defend the idea that "the artistic craftsperson creates original works that "bear the imprint of the personality of their author"' (Audugé 2013: 2). To do

23. The Chambers of Trades and Crafts (chambres des métiers et de l'artisanat) are public institutions representing the economic sector of arts and crafts at the level of French departments and regions.

24. On the supporters of this failed attempt, made in 1990, see Anne Jourdain's book (2014). 
intellectuelle qui ne fait pas mention de la notion d'utilité (voir supra) (Audugé $2013: 6$ ). AAF demande également une adaptation de la réglementation fiscale afin d'abolir la distinction entre art " pur » et art « appliqué ». Enfin, l'une des préconisations principales de la note de synthèse est d'établir une " simple présomption d'éligibilité au régime social des artistes auteurs, au profit des artisans d'art visés à l'annexe de l'arrêté du 12 août 2003 fixant la liste des métiers d'art " (Audugé 2013 : 11). Ainsi, sans renier ni renoncer à la notion d'artisanat, il s'agit d'en démontrer la valeur artistique et d'inclure les métiers d'art dans les politiques publiques artistiques. Toujours en 2013, un amendement parlementaire visant à la reconnaissance légale du secteur des métiers d'art est rédigé par AAF en collaboration avec l'Assemblée permanente des chambres de métier et de l'artisanat (APCMA) et l'Union nationale des métiers d'art (UNMA, une émanation d'AAF), et inscrit dans la loi artisanat, commerce et très petites entreprises, dite loi Pinel. Cette loi, qualifiée d'« historique » par la chambre syndicale, est promulguée le 19 juin 2014 et comporte deux éléments essentiels : la reconnaissance de l'existence des métiers d'art comme secteur économique, et la reconnaissance de la dimension artistique comme spécificité des métiers d'art (les artisans d'art étant, dès lors, des " créateurs "). Son décret d'application, publié au Journal officiel en janvier 2016, dresse par ailleurs la liste des métiers d'art (remplaçant la liste des métiers de l'artisanat d'art) suggérant que ces activités ne relèvent plus nécessairement de l'artisanat. Enfin, la Loi liberté de création, patrimoine et architecture votée en 2015 et adoptée par le Sénat le 29 juin 2016 complète la loi Pinel en précisant que la liste des métiers d'art nouvellement établie « ne préjuge pas du statut professionnel des personnes exerçant l'une des activités y figurant. Elles [les personnes exerçant un métier d'art] peuvent donc être aussi, notamment, des salariés d'entreprises artisanales ou de toute autre personne morale ayant une activité de métiers d'art, des professions libérales, des fonctionnaires ou des artistes auteurs " (article 14D). so, they drew in particular on the Intellectual Property Code, which does not mention the notion of utility (see above) (Audugé 2013: 6). AAF also asked for tax regulations to be changed to abolish the distinction between "pure" and "applied" art. Finally, one of the main suggestions of the summary note was to establish a "simple presumption of eligibility for the social regime of author artists, to benefit the artistic craftspeople referred to in the annex of the decree of August 12 2003, which established the list of craft professions" (Audugé 2013: 11). Thus, without denying or abandoning the notion of craftwork, the report sought to demonstrate its artistic value and to include the craft professions in artistic public policies. Also in 2013 , the $A A F$, in collaboration with the permanent assembly of chambers of trade (APCMA) and the National Union of Craft Professions (UNMA, an outgrowth of the AAF) wrote a parliamentary amendment seeking legal recognition of the craft profession sector which was included in the Craft, Commerce, and Very Small Businesses Act, the so-called "Pinel law." This law, which the trade association called "historic," went into effect on 19 June 2014 and included two essential elements: first, recognition of the existence of the craft professions as an economic sector, and second, recognition of the artistic aspect as a particularity of the craft professions (artistic craftspeople were henceforth "creators"). In addition, the decree implementing this law, which was published in the Official Journal in January 2016, established the list of craft professions [métiers d'arts] (which replaced the list of professions of craft art [métiers de l'artisanat d'art]), suggesting that these activities were no longer necessarily classified as craftwork. Finally, the Freedom of Creation, Patrimony, and Architecture Act, which was voted on in 2015 and adopted by the Senate on 29 June 2016, supplemented the Pinel Law by specifying that the newly established list of craft professions "does not prejudge the professional status of those individuals practising one of the activities listed. These individuals may also be, in particular, employees of craft businesses or any other legal entity practising a craft profession, a liberal profession, bureaucrats, or author artists" (Article 14D). 
Le cadre de cet article ne nous permet pas de le démontrer ${ }^{24}$ mais plusieurs facteurs expliquent la relative réussite de cette mobilisation par le droit, à commencer par les réorientations du répertoire tactique de la chambre syndicale dans les années 2000 combinées à un contexte plus général de restructuration des organismes de Sécurité sociale. Quoi qu'il en soit, contrairement à l'autonomisation conçue par Pierre Bourdieu comme un processus réalisé par les agents situés dans les espaces les plus autonomes, c'est-à-dire les plus éloignés du pouvoir politique et économique, l'autonomisation du groupe est plutôt générée, comme dans la théorie abbottienne, par une organisation leader dotée d'une position privilégiée au croisement des arènes professionnelles et politiques (Morel $2016: 316$ )

\section{Conclusion}

Distinguer la notion d'autonomie à l'aune des notions de champ et de ses déclinaisons montre que l'autonomie peut être parfaitement effective au sein d'un espace professionnel, alors même que celuici n'est pas nécessairement dénué de tensions et de dépendances. Ainsi, à travers ses segments (cabinets ministériels, travail de parlementaires, cours de justice) et leurs modalités d'action propres (bureaucratiques, politiques, juridiques), l'État produit des effets diversifiés mais jamais déterminés par avance, même si, aujourd'hui, certaines interventions publiques assoient et renforcent finalement les logiques d'autonomisation du groupe. La solidité de cette entité sociale est donc en partie liée à la réussite des différents paris engagés à ses frontières, au cœur des écologies liées, et non au cœur du groupe (Abbott 2016). Sans totalement priver les organisations représentatives ou régulatrices du groupe de leur pouvoir symbolique consistant à statuer sur la professionnalité des

24. Pour davantage de développements sur ce recours au droit, voir l'article de Flora Bajard (2018b).
It is beyond the scope of this article to show the various factors that explain the relative success of this mobilization via the law, beginning with the trade association reorienting its tactical repertoire in the 2000s, combined with a general context of the restructuring of social security agencies. ${ }^{25}$ In any case, contrary to autonomization as understood by Bourdieu-a process carried out by agents situated in the most autonomous spaces, that is, the furthest from political and economic power-the autonomization of the group is generated, instead, as in Abbott's theory, by a leader organization occupying a privileged position at the intersection of the professional and political arenas (Morel 2016: 316).

\section{Conclusion}

Distinguishing the notion of autonomy in relation to the notions of field and its various forms shows that autonomy can be fully effective within a professional space, even when the space is not necessarily free of tensions and dependencies. Thus, the state, through its various sectors (ministerial cabinets, parliamentary work, courts of law) and their specific modes of action (bureaucratic, political, legal), produces diverse effects that are never determined in advance even if, today, certain public interventions end up supporting and reinforcing the group's logics of autonomization. The solidity of this social entity is thus in part linked to the success of various bets made at its boundaries, within connected ecologies rather than at the centre of the group (Abbott 1995). Without totally depriving the group's representative or regulatory organizations of their symbolic power to decide on the professionalism of group members, these individual and collective procedures attempt to

25. For further considerations concerning this appeal to the law, see Flora Bajard's article (2018b) 
membres du groupe, ces démarches individuelles et collectives visent donc à créer un cadre officiel dans lequel les professionnels pourraient continuer à développer leurs conceptions de l'activité.

L'imbrication entre autonomie et hétéronomie est d'autant plus visible dans le cas exposé ici, puisqu'elle se déroule aux frontières du champ, là où la lutte autour des enjeux de définition et de potentiel renouvellement de ce dernier est la plus forte. En effet, qu'il s'agisse de judiciarisation ou de juridicisation, on observe dans les logiques portées par les tenants de l'ordre professionnel de la céramique (et des métiers d'art de manière générale via $\mathrm{AAF}$ ), un principe de consécration spécifique bien distinct du nomos du champ artistique. Autrement dit, nous ne sommes pas ici dans une situation ou « effets de corps » et " effets de champs » font « sens ensemble, à la fois pour contribuer à l'autonomisation [du] champ [artistique] et pour être au principe des formes de concurrence en son sein " (Willemez 2015 : 136-137). Au contraire, il s'agit d'une lutte aux frontières visant à un élargissement de ce champ par la subversion d'une partie de son nomos. D'ailleurs, dans des publications de La Revue de la céramique et du verre comme lors des entretiens, certaines prises de position assimilent les professionnels qui ont accepté le critère de la non-utilité à des « tricheurs » qui se sont conformés aux nomos dans son entièreté, tandis que ceux qui s'y sont opposés bénéficient d'une forte estime. Ce phénomène indique un aspect central de la lutte : il ne s'agit pas seulement d'entrer dans le champ artistique (ou celui de la culture légitime), mais aussi, dans une logique de subversion, d'entrer par la modification des règles du champ, et plus précisément, en y réintégrant les notions de fonctionnalité ou d'art « appliqué » 25 .

Flora Bajard Aix Marseille Univ, LEST (UMR 7317), Marseille, France

25. Je tiens à remercier chaleureusement les deux coordinateurs de ce numéro, ainsi que les personnes ayant évalué cet article, pour l'enrichissement apporté par leurs remarques et demandes d'approfondissement. create an official framework in which professionals can continue to develop their understanding of their work.

The imbrication of autonomy and heteronomy is especially visible in the case presented here, since it takes place at the boundaries of the field, where the struggle over definitions and their potential renewal is strongest. Indeed, whether it is a matter of judicialisation or juridification, we observe within the logics of those who belong to the professional order of ceramists (and the craft professions in general, via the AAF), a specific principle of recognition quite distinct from the nomos of the artistic field. In other words, the situation is not one in which "corporate effects" and "field effects" "make sense together, both in order to contribute to the autonomization of the artistic field and in order to be at the root of the forms of competition within it" (Willemez 2015: 136-137). Instead, there is a struggle at the borders that aims to enlarge this field by subverting part of its nomos. Furthermore, in publications such as La Revue de la céramique et du verre, as well as in interviews, the opinion is expressed that those professionals who have accepted the criterion of non-utility are "cheaters" who conformed to the nomos in its entirety, whereas those who opposed it are held in high esteem. This phenomenon indicates a central aspect of the struggle: it is not only a matter of entering the field of art (or of legitimate culture), but also, in a logic of subversion, of entering by changing the rules of the field-and, more specifically, of reintegrating the notions of functionality or "applied art." 26

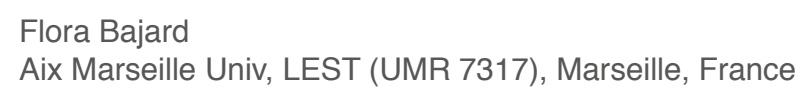

26. I would like to thank warmly the two co-ordinators of this issue, as well as everyone who helped enrich this article with their remarks and questions. 


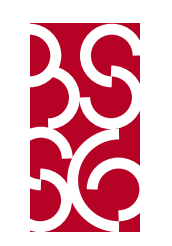

Fig. 3.

Une exposition dans une galerie d'art toulousaine, autour de la thématique de l'« orange ». La combinaison du lieu, de la scénographie ainsi que des objets présentés essentiellement des contenants, plus ou moins fonctionnels, mais uniques ou de très petites séries - brouille les repères ordinaires de l'art et de l'artisanat. Source : Photo personnelle de l'autrice.

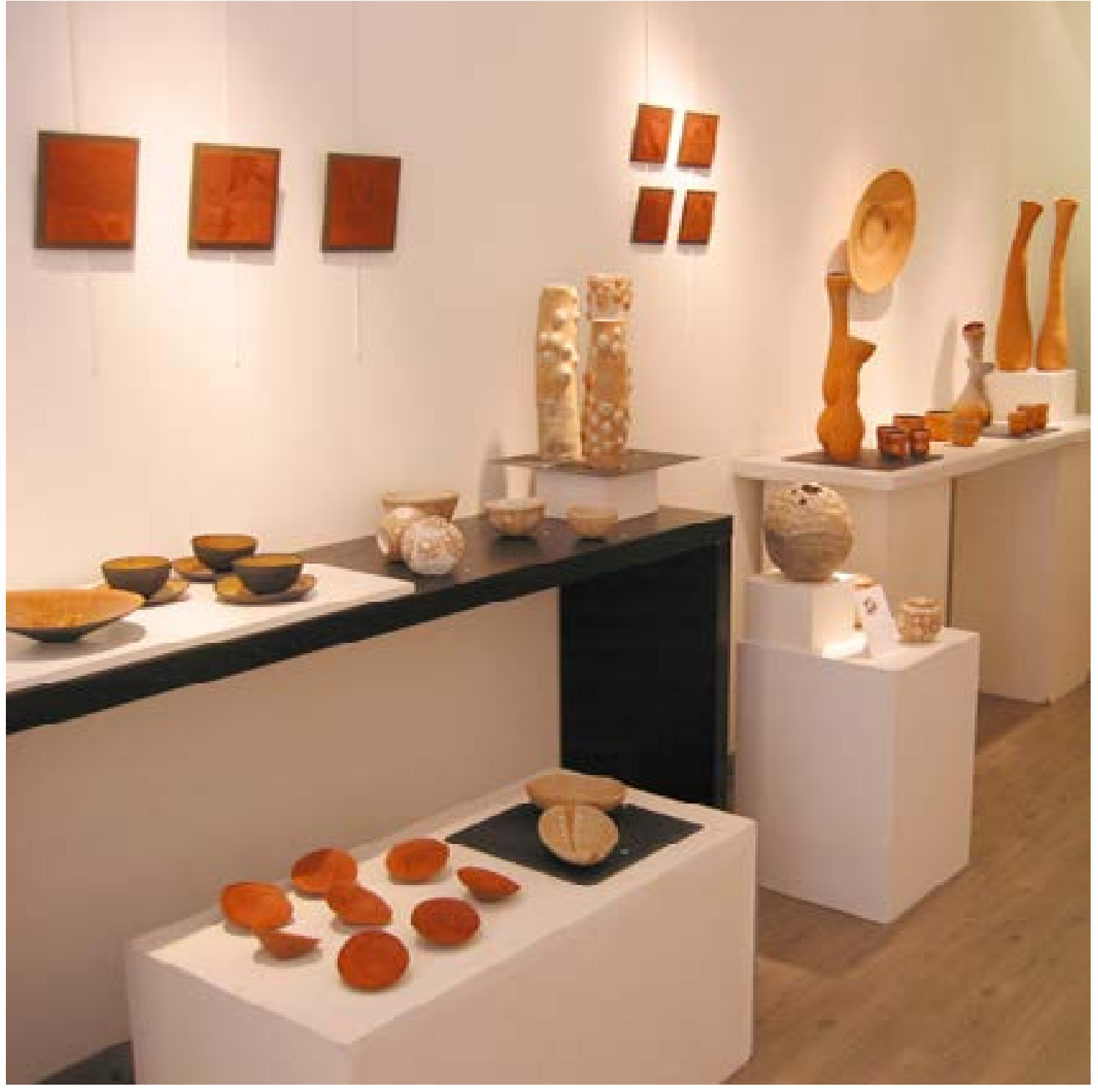

Fig. 3. An exhibit at a Toulouse art gallery with the theme

"orange." The combination

of site, scenography, and the

objects displayed-essentially

containers that are more or less

functional but are unique or

created in very small sets-blurs

traditional criteria of art and craft. Source: Author's personal photo. 


\section{Références bibliographiques}

Аввотт Andrew (2003). «Écologies liées : à propos du système des professions ». In MENGER Pierre-Michel. Les Professions et leurs sociologies. Paris, Maison des sciences de l'homme : 29-50.

Aввотт Andrew (2016). « Les choses des frontières ». In DemAZIĖRE Didier \& JouvENET Morgan (dir.). Andrew Abbott et l'héritage de l'école de Chicago. Paris, Éditions de l'EHESS : 119-144.

Audugé Sophie \& Ateliers d'ART de France (2013). Note de synthèse sur les artisans d'art, leur affiliation au régime des artistes-auteurs et le régime fiscal qui leur est applicable.

BAJARD Flora (2014). «L'invention de la céramique d'art. Contribution à la sociologie de la construction des groupes professionnels ». Sociologie du travail, 57(3) : 299-321.

BAJARD Flora (2018a). Les Céramistes d'art en France. Sens du travail et styles de vie. Rennes, Presses Universitaires de Rennes.

BAJARD Flora (2018b). «Les céramistes d'art contre "l'État" : la confrontation comme troisième voie de professionnalisation ». In BAJARD Flora et al. (dir.) Professionnalisation(s) et État. Une sociologie politique des professions. Villeneuve-d'Ascq, Presses Universitaires du Septentrion.

BECKER Howard S. (1978). "Arts and crafts ». American Journal of Sociology, 83(4) : 862-889.

BOURDIEU Pierre (1976). « Le champ scientifique », Actes de la recherche en sciences sociales, $2: 88-104$.

BOURDIEU Pierre (1977). « La production de la croyance ». Actes de la recherche en sciences sociales, $13: 3-43$.

\section{References}

Aввотт Andrew (2003). "Écologies liées: à propos du système des professions." In MeNGeR Pierre-Michel. Les Professions et leurs sociologies. Paris, Maison des sciences de l'homme: 29-50.

Аввотт Andrew (1995). "Things of boundaries." Social Research, 62(4): 857-882

Audugé Sophie and Ateliers d'ARt de France (2013). "Note de synthèse sur les artisans d'art, leur affiliation au régime des artistes-auteurs et le régime fiscal qui leur est applicable."

BAJARD Flora (2014). "L'invention de la céramique d'art. Contribution à la sociologie de la construction des groupes professionnels." Sociologie du travail, 57(3): 299-321.

BAJARD Flora (2018a). Les Céramistes d'art en France. Sens du travail et styles de vie. Rennes, Presses Universitaires de Rennes.

BAJARD Flora (2018b). "Les céramistes d'art contre 'l'État': la confrontation comme troisième voie de professionnalisation." In BAJARD Flora et al. (eds.). Professionnalisation(s) et État. Une sociologie politique des professions. Villeneuve-d'Ascq, Presses Universitaires du Septentrion.

BECKER Howard S. (1978). "Arts and crafts." American Journal of Sociology, 83(4): 862-889.

BOURDIEU Pierre (1976). "Le champ scientifique." Actes de la recherche en sciences sociales, 2: 88-104.

BourdieU Pierre (1980). "The Production of Belief: Contribution to an Economy of Symbolic Goods." Translated by Richard Nice. Media, Culture and Society, 2: 261-293. 
BouRdieu Pierre (1991). « Le champ littéraire ». Actes de la recherche en sciences sociales, $89: 3-46$.

Bourdieu Pierre (2012). Sur l'État. Cours au Collège de France (19891992). Paris, Seuil/Raisons d'agir.

Bourdieu Pierre (2015). Sociologie générale. Cours au Collège de France 1981-1983. Paris, Seuil.

DemAZIÈRE Didier (2009). «Postface. Professionnalisations problématiques et problématiques de la professionnalisation ». Formation emploi, 108(4) : 83-90.

Dozo Björn-Olav (2009). «Sociabilités et réseaux littéraires au sein du sous-champ belge francophone de l'entre-deux-guerres ». Histoire \& mesure, XXIV, $1: 43-72$.

HEINICH Nathalie \& SHAPIRO Roberta (dir.) (2012). De l'artification enquêtes sur le passage à l'art. Paris, EHESS.

JouRdAIn Anne (2014). Du cœur à l'ouvrage. Les artisans d'art en France. Paris, Belin.

LAHIRE Bernard (2006). La Condition littéraire. La double vie des écrivains. Paris, La Découverte.

MARCHETTI Dominique (2002). « Les sous-champs spécialisés du journalisme ». Réseaux, $111: 22-55$.

Morel Stanislas (2016). « $A u(x)$ cœur(s) des professions. Penser le rapport des professions à l'hétéronomie avec Abbott et Bourdieu ». In Demazière Dominique \& Jouvenet Morgan (dir.). Andrew Abbott et l'héritage de l'école de Chicago. Paris, Éditions de l'EHESS : 315-334.
BOURDIEU Pierre (1991). "Le champ littéraire." Actes de la recherche en sciences sociales, 89 : 3-46.

BOURDIEU Pierre (2015). On the State. Lectures at the Collège de France, 1989-1992. Translated by David Fernbach. Cambridge, Polity Press.

BouRdieu Pierre (2015). Sociologie générale. Cours au Collège de France 1981-1983. Paris, Seuil.

DEMAZIĖRE Didier (2009). "Postface. Professionnalisations problématiques et problématiques de la professionnalisation." Formation emploi, 108(4): 83-90.

Dozo Björn-Olav (2009). "Sociabilités et réseaux littéraires au sein du sous-champ belge francophone de l'entre-deux-guerres." Histoire \& mesure, XXIV, 1: 43-72.

HEINICH Nathalie \& SHAPIRO Roberta (2012). De l'artification enquêtes sur le passage à l'art. Paris, EHESS.

JouRdaIn Anne (2014). Du cœur à l'ouvrage. Les artisans d'art en France. Paris, Belin.

LAHIRE Bernard (2006). La Condition littéraire. La double vie des écrivains. Paris, La Découverte.

MARCHETTI Dominique (2002). "Les sous-champs spécialisés du journalisme." Réseaux, 111: 22-55.

MoREl Stanislas (2016). "Au(x) cœur(s) des professions. Penser le rapport des professions à l'hétéronomie avec Abbott et Bourdieu." In DeMAZIĖRE Dominique \& JOUVENET Morgan (eds.). Andrew Abbott et l'héritage de l'école de Chicago. Paris, Éditions de l'EHESS: 315-334. 
Moulin Raymonde (1983). « De l'artisan au professionnel : l'artiste ». Sociologie du travail, 4 : 388-403.

Moulin Raymonde (1992). L'Artiste, l'institution et le marché. Paris, Flammarion.

PÉLISSE Jérôme (2009). « Judiciarisation ou juridicisation ? Usages et réappropriations du droit dans les conflits du travail ». Politix, 86(2) : 73.

Poliak Claude (2006). Aux frontières du champ littéraire. Sociologie des écrivains amateurs. Paris, Economica.

SACRISTE Guillaume (2014). «Sur les logiques sociales du champ du pouvoir européen. L'exemple de l'affaire Dalli ». Politique européenne, $44: 52-96$.

VAUCHEZ Antoine (2008). «The Force of a Weak Field : Law and Lawyers in the Government of the European ». International Political Sociology, 2(2) : 128-144.

VAuchez Antoine \& GeORGAdAKIS Didier (2015). « Le champ à l'épreuve de l'Europe ». In SIMÉANT Johanna (dir.). Guide de l'enquête globale en sciences sociales. Paris, CNRS Éditions : 197-217.

WILLEMEZ Laurent (2015). « Un champ mis à l'épreuve. Structure et propriétés du champ juridique dans la France contemporaine ». Droit et société, 89 : 129-149.
MoULIN Raymonde (1983). "De l'artisan au professionnel: l'artiste." Sociologie du travail, 4: 388-403.

Moulin Raymonde (1992). L'Artiste, l'institution et le marché. Paris, Flammarion.

PÉLISSE Jérôme (2009). "Judiciarisation ou juridicisation ? Usages et réappropriations du droit dans les conflits du travail." Politix, 86(2): 73.

Poliak Claude (2006). Aux frontières du champ littéraire. Sociologie des écrivains amateurs. Paris, Economica.

SACRISTE Guillaume (2014). "Sur les logiques sociales du champ du pouvoir européen. L'exemple de l'affaire Dalli." Politique européenne, 44 52-96.

VAUCHEZ Antoine (2008). "The Force of a Weak Field: Law and Lawyers in the Government of the European." International Political Sociology, 2(2): 128-144.

VAUCHEZ Antoine \& GeORGADAKIS Didier (2015). "Le champ à l'épreuve de l'Europe." In SIMÉANT Johanna. Guide de l'enquête globale en sciences sociales. Paris, CNRS Éditions: 197-217.

WILLEMEZ Laurent (2015). "Un champ mis à l'épreuve. Structure et propriétés du champ juridique dans la France contemporaine." Droit et société, 89: 129-149. 